\title{
NOVA DIREÇÃO
}

Recebemos do Professor José Salgado Martins, eminente Diretor de nossa Faculdade, a missão de prosseguir na obra de precursores ilustres que consclidaram o nome e o conceito desta Revista de nossa querida Faculdaće de Direito. Confiamos poder receber o apoio e colaboração de professores, juristas, advogados, magistrados, procuradores, alunos e quantos mais labutam no setr jurídico, para poder levar a termo o honroso encargo, de que não nos arreceamos face à certeza da referida e indispensável cooperação.

Agradecêmo-la, antecipadamentre, em nome da Revista, de seu corpo redatorial e da própria Faculdade.

PROF. DR. ERICO MACIEL FILHO 